and adiponectin. Method and Result IPC model and MI model was set up. The protective effect of IPC was studied by measuring infarction size with Masson's Trichrome staining. The expression of protein and mRNA of adiponectin was examined by immunohistochemistry and quantitative real time RT-PCR o h, $6 \mathrm{~h}, 12 \mathrm{~h}$ and $24 \mathrm{~h}$ after IPC. And the plasma levels of adiponectin at four time points after IPC was also detected by ELISA. IPC reduced infarct size compared with control MI model ( $20 \pm 2 \% \mathrm{LV}$ area vs $31 \pm 3 \% \mathrm{LV}$ area, $\mathrm{p}<0.05)$. The expression of adiponectin mRNA $6 \mathrm{~h}$ and $12 \mathrm{~h}$ after the IPC was 2.2 and 2.1 times greater than the sham group $(p<0.05)$ and the expression of adiponectin protein was siginificantly higher than non-ischaemic area $(p<0.05)$. Compared to the sham groups, the plasma level of adiponectin increased significantly $0 \mathrm{~h}, 6 \mathrm{~h}$ and $12 \mathrm{~h}$ after IPC (0 h:7.40 \pm 0.47 vs $10.90 \pm 1.74 ; 6 \mathrm{~h}: 8.18 \pm 1.41$ vs $10.98 \pm 1.74 ; 12 \mathrm{~h}: 6.97 \pm 1.02$ vs $9.31 \pm 0.96, \mathrm{p}<0.05)$.

Conclusion Late IPC reduced infarction size and improved the expression of adiponectin mRNA and protein in myocardium, and also improved the concentration of adiponectin in plasma, which indicates that the adiponecitn may play a role in the protective effect of IPC.

\section{e0117 THE FOUNDATION RESEARCH OF RENAL DENERVATION IN THE TREATMENT OF HYPERTENSION IN CANINE}

doi:10.1136/hrt.2010.208967.117

${ }^{1}$ Lu Chengzhi, ${ }^{2}$ Liu Jia, ${ }^{1}$ Zhang Xin. ${ }^{1}$ First Center Hospital of Tianjin; ${ }^{2}$ Medical University of Tianjin

Objective To explore relationship between sympathetic activity and mechanism of hypertension, observe the treatment of renal artery denervation for hypertension, to assess the validity and safety of the treatment.

Methods 18 mongrel dogs were divided into two groups, 10 dogs were made to neurogenic hypertension model through the compression of the demyelinated vagus nerve by carotid sheath vessels pulse, another eight as the control group, two groups were operated by renal arterial radiofrequency ablation with $10 \mathrm{w}$ power, no more than $60^{\circ} \mathrm{C}$, at least $2 \mathrm{~min}$. Blood pressure and other parameters were monitored at preoperative and 1 week, 2 weeks, 4 weeks, 10 weeks post operation. Renin activity, angiotensin II, aldosterone, and creatinine were measured at the same time.

Results we succeed in establishing the canine neurogenic hypertension model and the blood pressure were substantially reduced after sympathetic denervation. After modelling, the systolic pressure increased from $155.7 \pm 21 \mathrm{~mm} \mathrm{Hg}$ to $179.5 \pm 23 \mathrm{~mm} \mathrm{Hg}$, and the diastolic pressure increased from $117.4 \pm 18.9 \mathrm{~mm} \mathrm{Hg}$ to $138.2 \pm 13.4 \mathrm{~mm} \mathrm{Hg}$, there was a significant difference $(p<0.01)$. Blood pressure decreased significantly in both the control group and blank group after renal denervation at 2 weeks, 4 weeks, 10 weeks, especially after ablation 10 weeks the blood pressure decreased more obviously (systolic blood pressure $179.5 \pm 23 \mathrm{~mm} \mathrm{Hg}$ vs $143.9 \pm 11.7 \mathrm{~mm} \mathrm{Hg}$, diastolic blood pressure $138.2 \pm 13.4 \mathrm{~mm} \mathrm{Hg}$ vs $114.9 \pm 15.5 \mathrm{~mm} \mathrm{Hg}$, $\mathrm{p}<0.001$ ). Renin activity (PRA), Angiotensin II (Ang II) and aldosterone (Ald) levels were decreased after ablation, the levels of PRA detected preoperative, 1 week, 2 weeks, 4 weeks and 10 weeks after ablation were $0.26 \pm 0.09 \mathrm{ng} / \mathrm{ml} / \mathrm{h}, \quad 2.2 \pm 1.44 \mathrm{ng} / \mathrm{ml} / \mathrm{h}, \quad 0.71 \pm 0.57 \mathrm{ng} / \mathrm{ml} / \mathrm{h}$, $0.49 \pm 0.35 \mathrm{ng} / \mathrm{ml} / \mathrm{h}, 0.24 \pm 0.12 \mathrm{ng} / \mathrm{ml} / \mathrm{h}$, the levels of Ang II were $76.9 \pm 14.3 \mathrm{pg} / \mathrm{ml}, 120 \pm 25.2 \mathrm{pg} / \mathrm{ml}, 97.1 \pm 21.9 \mathrm{pg} / \mathrm{ml}, 76.5 \pm 13.7 \mathrm{pg} /$ $\mathrm{ml}, \quad 64.4 \pm 11.1 \mathrm{pg} / \mathrm{ml}$, the levels of Ald were $1.8 \pm 1.27 \mathrm{ng} / \mathrm{dl}$, $7.5 \pm 1.73 \mathrm{ng} / \mathrm{dl}, 6.6 \pm 3.34 \mathrm{ng} / \mathrm{dl}, 4.6 \pm 2.59 \mathrm{ng} / \mathrm{dl}, 3.3 \pm 1.61 \mathrm{ng} / \mathrm{dl}$. But the levels of $\mathrm{Cr}$ were not changed too much, it shows no great difference $(57 \pm 12.7 \mathrm{umol} / \mathrm{l}, 45 \pm 7.4 \mathrm{umol} / 1,36 \pm 19.2 \mathrm{umol} / 1,43 \pm 8.6 \mathrm{umol} / \mathrm{l}$, $41 \pm 21.8 \mathrm{umol} / \mathrm{l} \mathrm{p}>0.05)$.

Conclusion Sympathetic nerves accelerate the development and progression of hypertension, catheter-based renal denervation causes substantial and sustained blood pressure reduction, and it cause no injury on renal, If in the future it can be widely applied in the treatment of hypertension, it will have broad application prospects and huge social benefits.

\section{Q0118 THE MYELOPEROXIDASE INHIBITOR, AMINOBENZOIC ACID HYDRAZIDE, ALTERS NEUTROPHIL-ENDOTHELIAL CELL INTERACTION}

doi:10.1136/hrt.2010.208967.118

Han Lili, Shen Xiaoli, Lin Saimei, Pan Leng, Liu Xiaoging, Pu Xiaodong, Deng Yulian, Guo Conghua. Affiliated Fujian Provincial Hospital, Fujian Medical University/Fujian Provincial Key Laboratory of Cardiovascular Disease

Objective Acute myocardial infarctions (AMI) are associated with vascular inflammation, including activation of neutrophils and their adherence to vascular endothelial cells via CD11b/CD18 binding to intercellular adhesion molecule (ICAM). Myeloperoxidase (MPO) is an inflammatory biomarker, can induce CD11b surface expression in polymorphonuclear neutrophils (PMNs), but its role in regulating adhesion is not well characterised. MPO's role in regulating adhesion was further investigated by comparing the effects of aminobenzoic acid hydrazide (ABAH), an inhibitor of $\mathrm{MPO}$, antibodies specific for $\mathrm{CD} 11 \mathrm{~b}$ and vehicle control on PMN adhesion to endothelial cells.

Methods Human neutrophils were isolated from the peripheral blood of patients with AMI or healthy participants using Percoll density gradient centrifugation. The effects of $\mathrm{ABAH}$ and anti$\mathrm{CD} 11 \mathrm{~b}$ antibodies on neutrophil adhesion to endothelial cell were measured using adhesion assays.

Results The adhesion rate was significantly higher for neutrophils isolated from AMI patients than healthy individuals $(p<0.001)$. Neutrophil adhesion was reduced upon treatment with $\mathrm{ABAH}$ in a dose dependent manner. The adhesion rate was significantly reduced in neutrophils treated with $10 \mu \mathrm{M}$ and $20 \mu \mathrm{M}$ ABAH as compared to the untreated group. Treatment with anti-CD11b antibodies also significantly reduced neutrophil adhesion compared to the untreated control group $(\mathrm{p}<0.001)$.

Conclusions MPO might enhance the neutrophils adhesions to endothelial cells in AMI patients through the upregulation of $\mathrm{CD} 11 \mathrm{~b}$ expression in the suface of neutrophils. The interference of cell adhesion by $\mathrm{ABAH}$ may be mediated by reduced $\mathrm{CD} 11 \mathrm{~b}$ expression in neutrophils.

Acknowledgements This work was supported by grants from the Nature Science Foundation of Fujian Province (2006J0326, X0650036) and the Science and Technology Planning Project of Fujian Province (20050006).

\section{E0119 CARDIOPROTECTIVE EFFECT OF PI3K/AKT PATHWAY IN ISCHAEMIC POSTCONDITIONING AGAINST ISCHAEMIA AND REPERFUSION INDUCED INJURY IN ISOLATED RAT HEART}

doi:10.1136/hrt.2010.208967.119

Zhao Xin, Quan NanHu. Department of Cardiology, First Hospital of Jilin University, Chang Chun, China

Objective To explore the cardioprotection effect of co-treatment with ischaemic postconditioning and the mechanism of PI3K/Akt signal pathway in ischaemia postconditioning.

Methods 32 healthy adult male Wistar rats were assigned randomly into ischaemia/reperfusion group (I/R), ischaemia postconditioning group (IPost), IPost+Wortmannin group (IPost $+W), \quad I / R+$ SB216763group $(I / R+S B)$, each group has eight rats. Rats were used for Langendorff isolated heart perfusion. The hearts were subjected to global ischaemia for $30 \mathrm{~min}$ followed by $60 \mathrm{~min}$ reperfusion. The cardia injury was evaluated by the levels of lactate dehydrogenase $(\mathrm{LDH})$ and Creatine kinase $(\mathrm{CK})$ in the coronary effluent. 